\title{
Sand-spits systems from Benguela region (SW Angola). An analysis of sediment sources and dispersal from textural and compositional data
}

\author{
Pedro A. Dinis ${ }^{\text {a, * }}{ }^{\text {, João Huvi }}{ }^{\text {, }}$, João Cascalho ${ }^{\text {c, d }}$, Eduardo Garzanti ${ }^{\text {, }}$, Pieter Vermeesch ${ }^{\text {f }}$, \\ Pedro Callapez ${ }^{\mathrm{g}}$ \\ ${ }^{a}$ MARE - Marine and Environmental Sciences Centre, Departamento de Ciências da Terra da Universidade de Coimbra, 3030-790 Coimbra, Portugal \\ ${ }^{\mathrm{b}}$ MARE - Marine and Environmental Sciences Centre, University Katiavala Bwila, Angola \\ c Instituto Dom Luiz e Departamento de Geologia da Faculdade de Ciências da Universidade de Lisboa, 1749-016 Lisboa, Portugal \\ ${ }^{\mathrm{d}}$ Museu Nacional de História Natural e da Ciência Universidade de Lisboa, 1250-102 Lisboa, Portugal \\ e Department of Earth and Environmental Sciences, University of Milano-Bicocca, 20126, Milano, Italy \\ ${ }^{\mathrm{f}}$ University College London, London, WC1E 6BT, UK \\ g Centre for Earth and Space Research of the University of Coimbra, Departamento de Ciencias da Terra da Universidade de Coimbra, 3030 -790 Coimbra, \\ Portugal
}

\section{A R T I C L E I N F O}

\section{Article history:}

Received 19 June 2015

Received in revised form

13 January 2016

Accepted 14 January 2016

Available online 16 January 2016

\section{Keywords:}

Coastal Angola

Sand spits

Provenance

Grain-size distribution

Heavy minerals

Clay minerals

\begin{abstract}
A B S T R A C T
Sand spits are important coastline features in western Angola, but only limited knowledge on their recent evolution and sediment sources were obtained so far. The present study is focused on the Baía Farta and Lobito sand spits of coastal Benguela that develop to the north (i.e. downdrift) of the Coporolo and Catumbela river outlets. We used grain-size distributions, heavy-mineral suites and clay-mineral assemblages of sediments in the Coporolo-Baía Farta and Catumbela-Lobito coastal stretches to characterize the main depositional units and investigate sediment provenance. From the combined grain-size and mineralogical variability in mud and sand samples it is possible to infer sediment sources and dispersal in the two coastal stretches. Kaolinite is mainly derived from the Angola hinterland, and is particularly common in finer grained floodplain sediments from the Catumbela River. Expansive clays (smectite and illite-smectite mixed layers) are inferred to be mainly sourced by Meso-Cenozoic units of the Benguela Basin, being abundant in coarser grained fluvial deposits and in lagoonal deposits near Baía Farta. Sand supplied by the sedimentary units from Benguela Basin and their basement rocks tends to be enriched in epidote associated with blue-green hornblende. The Coporolo River sand is progressively diluted during the longshore northward transport by sand supplied by coastal units. Conversely, beach deposits in the Catumbela-Lobito coastal stretch are mainly sourced by the Catumbela River. A divergent longshore transport from Catumbela river-mouth occurs at Catumbela delta. Sand spit morphology and evolution reflect the patterns of dispersal of bedload and suspended load in settings of contrasting orography and human influence.
\end{abstract}

(c) 2016 Elsevier Ltd. All rights reserved.

\section{Introduction}

Sand spits are shoreline accumulations that frequently form in places of sudden change in mainland orientation where coastal sands are reworked by waves and transported downdrift from local points of sediment discharge (e.g., river mouths). Highly dynamic sand spits sourced by mouth-bars or abandoned delta lobes are common shoreline forms in wave-dominated deltas (Rodriguez

\footnotetext{
* Corresponding author.

E-mail address: pdinis@dct.uc.pt (P.A. Dinis).
}

et al., 2000; Van Maren, 2005; Nienhuis et al., 2013), being built up by wave-induced longshore currents and cross-shore processes (Jiménez and Sánchez-Arcilla, 2004; Dan et al., 2011). In some situations of prevalent longshore transport where fluvial bedload is continuously carried downdrift the sand spits are associated with deflected deltas (Wright, 1985; Bhattacharya and Giosan, 2003). Occasionally the sand spits are genetically related to prograding strandplains that display a characteristic succession of beach ridges (Otvos, 2000; Tamura, 2012). Conceptual models proposed for the development of sand spits in deltaic coasts emphasize the dynamic behaviour of the shoreline accumulations and the cyclic character of the forming processes (Penland et al., 1988; Campbell, 2005; Dan 
et al., 2011). Small sand spits are usually considered ephemeral features, whilst the larger shoreline forms are more persistent and result from long-term process, but regardless of their size and dynamics, sand spit evolution is expected to be conditioned by the location and nature of their sediment sources (Anthony, 2015).

The Lobito and Baía Farta sand spits are two important shoreline forms of costal Benguela. The Lobito sand spit is a $5 \mathrm{~km}$-long linear barrier that constitutes a natural protection for the city bay and harbour and exhibits a dense human occupation with numerous well prized buildings. The risk of natural breaching during storms coupled with the need to limit the growth of the sand spit led to the development of a series of groynes during the 1960s. The Baía Farta spit is shorter (1.5 km long) and its human occupation is rooted in the fishing activity. Although the real estate value of Baía Farta is not comparable to Lobito, Baía Farta does have significant economic importance as one of the most important fishing centres in Angola. Despite occasional events of rapid erosion along the sand spit responsible for the destruction of docks and warehouse, no notable structures for coastal protection were implemented in this sand spit.

Littoral Benguela sand spits are placed NE of the Catumbela and Coporolo rivers, in coastal areas characterized by the presence of sandy beach-ridge systems associated with strandplains and protruding deltas. These morphosedimentary settings suggest that the spits developed in prograding coasts are fed from rivers to the south. However, other sources besides the Catumbela and Coporolo rivers, such as smaller littoral streams and coastal cliffs could contribute important amounts of sediment (Carvalho, 1963). Additionally, there is no complete understanding of the relative contribution of bedload and suspend load to the coastal systems from different areas within each river catchment and of the pattern of sediment dispersal along the coastal zone. A good control of sediment sources and dispersal is crucial for understanding the dynamics of these sensitive littoral environments.

In the present research, sediment grain-size, heavy-mineral and clay-mineral assemblages are used to investigate the sediment sources for the Coporolo-Baía Farta and Catumbela-Lobito sand spit systems and to differentiate the two based on the spatial trends in textural and compositional features. The main goals are to: 1) determine the main sources of sediment for the two sand spit systems, 2) evaluate the connectivity between coastal stretches in littoral Benguela, and 3) contribute to the understanding of the dispersal processes that influence present-day shoreline morphology of West Angola.

\section{Study area}

\subsection{Geology and geomorphology}

A prominent feature of SW Angola is the presence of flat surfaces that decrease in elevation westward and are separated by escarpments of variable altitude (Diniz, 2006). A divide separating the Atlantic drainage from the catchments of the Kunene and Cubango rivers is located in a mountain range that strikes broadly parallel to the Atlantic coast. Paleoproterozoic and Archean units that belong to the Angola Block of the Congo Craton (Heilborn et al., 2008; de Waele et al., 2008) crop out through this area (Fig. 1). Diverse igneous rocks, chiefly associated with the Paleoproterozoic Eburnean orogenic cycle (2.1-1.8 Ga), are observed in the southern sector of the Angola Block (Carvalho et al., 2000; Pereira et al., 2011). To the west a poly-orogenic complex mainly composed of schist, quartzite and amphibolite with subordinate igneous rocks is exposed. In general, the basins from the Angolan margin rest on this poly-orogenic complex (Carvalho, 1980, 1983).

The Angolan Atlantic margin is part of the central segment of the
South Atlantic Ocean, being characterized by the presence of extensive Aptian salt deposits that conditioned the subsequent geological evolution (Moulin et al., 2005). The Angolan margin displays an abrupt decrease in crustal thickness beneath the continental slope and a sector with depositional accumulation $(>10 \mathrm{~km}$ thick) overlying extremely thin continental crust (Contrucci et al., 2004; Moulin et al., 2005; Aslanian et al., 2009). It is considered a non-volcanic margin, contrasting with the Namibia volcanic margin to the south (Contrucci et al., 2004; Seranne and Anka, 2005; Moulin et al., 2005; Chaboureau et al., 2013).

The so-called Benguela Basin, extending onshore north of the poly-orogenic outliers of the Lucira region (Fig. 1B, D), is separated from the Kwanza Basin by the Kwanza volcanic seamount (Marzoli et al., 1999). Several authors, however, on the basis of the nature of the Meso-Cenozoic infill and the geometric relations with the basement, consider only three basins in the Angolan margin (Lower Congo, Kwanza and Namibe), and view the Benguela sub-basin as the southernmost sector of the Kwanza Basin (e.g. Buta-Neto et al., 2006; Quesne et al., 2009; Guiraud et al., 2010). Guiraud et al. (2010) emphasise the geomorphological differences between the transform-rifted Benguela Basin and the oblique-to-orthogonal rifted Kwanza Basin. According to these authors, the Benguela margin is conditioned by a postulated Benguela transform, trending approximately N50 between the Cuio and Lucapa fault zones (Fig. 1D). The Benguela margin displays a low relief coastal sector that is limited offshore by a steep slope and inland by a high-elevation escarpment, contrasting with the northern Angola margin of much gentler relief. These morphological features may be explained by major post-rift (i.e., post-lower Aptian) uplift when compared to the Kwanza Basin (Guiraud et al., 2010). Prominent uplift is particularly evident for the late Cenozoic of SW Angola (Giresse et al., 1984; Guiraud et al., 2010) and explains the relatively steepness of the main regional rivers (Catumbela and Coporolo) and shortness of the respective drainage basins (Guiraud et al., 2010). The high post-rift uplift rate also justifies the extremely narrow continental shelf in SW Angola, in particular along the coastal stretch between the Coporolo river mouth and the Baía Farta spit, where the 100 and $200 \mathrm{~m}$ isobaths are frequently as close as ca. 1 and $1.3 \mathrm{~km}$ from the shoreline, respectively (Fig. 2).

\subsection{Climate}

The climate of SW Angola is characterized by alternating wet and dry seasons varying with latitude and distance from the coastline. The month with highest rainfall ranges from January (in eastern locations) to March (in western locations). The dry season usually runs from May to September and is colder. Given its latitude $\left(17-10^{\circ} \mathrm{S}\right)$ and the influence of the Benguela upwelling system, which is responsible for low sea-surface temperatures and low-humidity southerly winds, climate along coastal SW Angola is arid (Fig. 1C). The cold northward-flowing Benguela current converges with the warm southward-flowing Angola Current establishing an oceanic circulation of global relevance (Shannon and Nelson, 1996; Diester-Hass et al., 2002). The intensity of the two currents and the position of their convergence zone, the Angola-Benguela front, are seasonally variable and usually shift between $14^{\circ} \mathrm{S}$ and $16^{\circ} \mathrm{S}$ (Hardman-Mountford et al., 2003). In accordance with this circulation pattern, aridity becomes less severe northward, in particular to the north of the AngolaBenguela front (Fig. 1C).

Rainfall also increases significantly eastward. In accordance, climate shifts from the hot desert type in littoral areas of southern Angola (BWh of Koppen's classification) to hot semi-arid in the west Benguela region (Bsh); eastwards it becomes humid sub- 

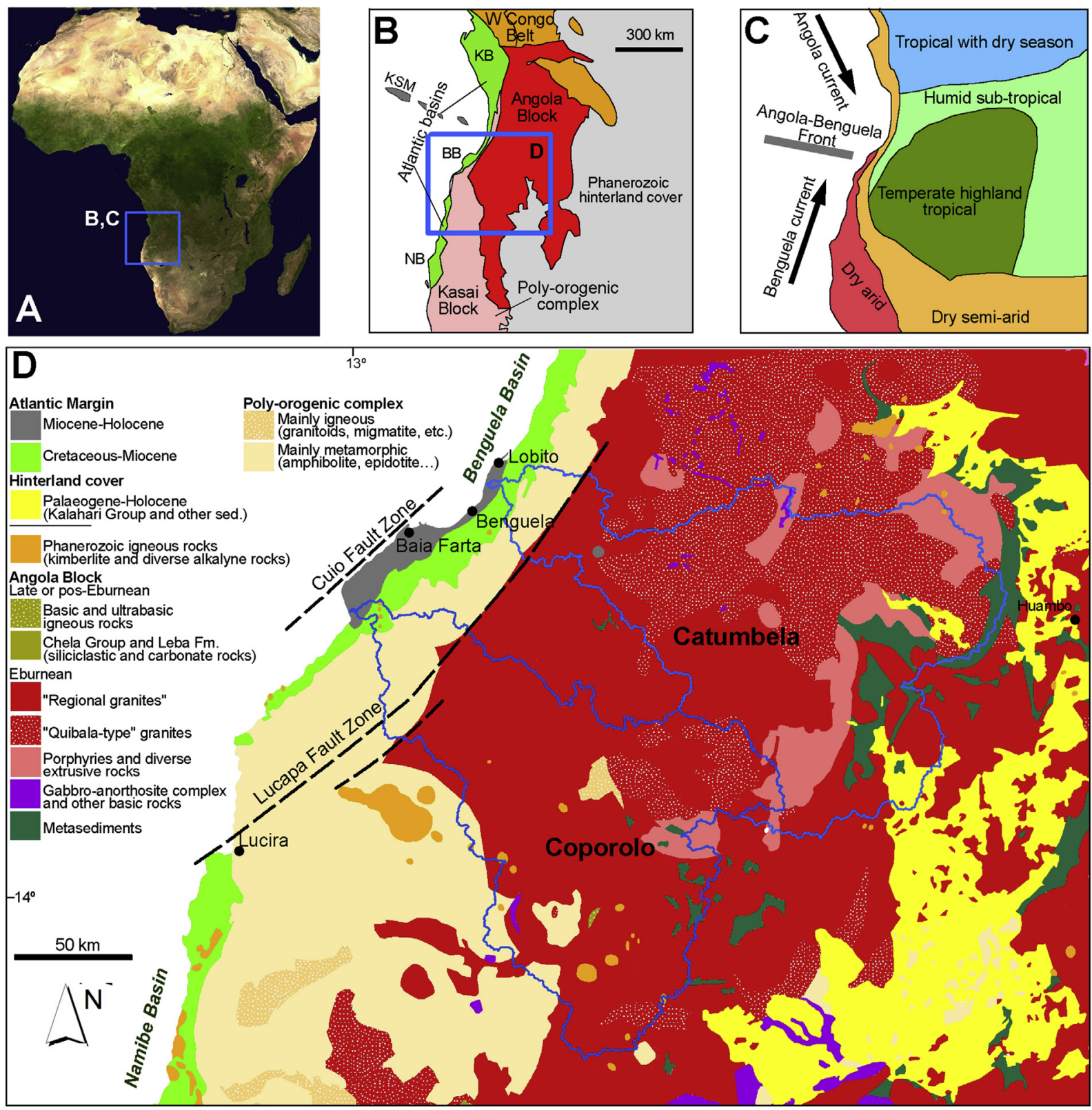

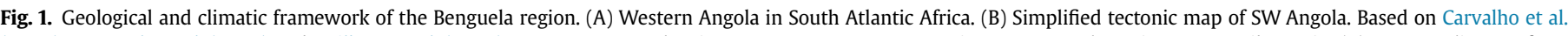

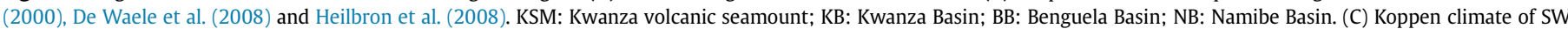

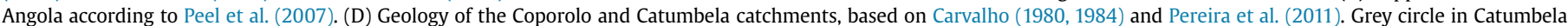
catchment shows location of sample collected outside Fig. 2.

tropical (Cwa) and temperate highland tropical with dry winters (Cwb; Peel et al., 2007) (Fig. 1C). Weak southerly to south-westerly winds are prevalent in the coastal region all over the year, even though an inversion can take place during the night when continental areas become colder than the ocean.

\subsection{Coastal morphology and processes}

Mean tide amplitude in southwest Angola is approximately $1 \mathrm{~m}$. The amplitude of spring tides in Benguela is usually $1.25-1.5 \mathrm{~m}$, whereas neap tides are less than $1 \mathrm{~m}$. Limited data are available for the wave regime. A single-year time series from the Lobito area indicates wave vectors ranging $265^{\circ}-295^{\circ}$, a maximum significant wave height of $1.75 \mathrm{~m}$, with a mode of $0.5 \mathrm{~m}$ (Abecassis, 1958). The region is periodically affected by high-energy wave events (locally called "calema"), for which data are lacking. This combination of tide and wave conditions is symptomatic of a wave-dominated setting (Davis and Hayes, 1984; Roy et al., 1994).

Sequences of beach-ridges are observed near the outlets of the Coporolo and Catumbela rivers. The most extensive beach-ridge system, up to almost $5 \mathrm{~km}$ shore-transverse and $45 \mathrm{~km}$ shoreparallel, constitutes a strandplain developed mainly on the downdrift side (northeast) of the Coporolo river valley (Fig. 2). The succession of beach ridges is somewhat discontinuous, becoming thinner near the mouth of short littoral streams (Calupele and Dungo) and gaining new expression immediately downdrift. The Baía Farta spit is found at the northward termination of the Coporolo beach-ridge system. The Catumbela and Cavaco beach-ridge systems can be traced along both sides of the respective river outlets. The Catumbela delta is a typical case of 


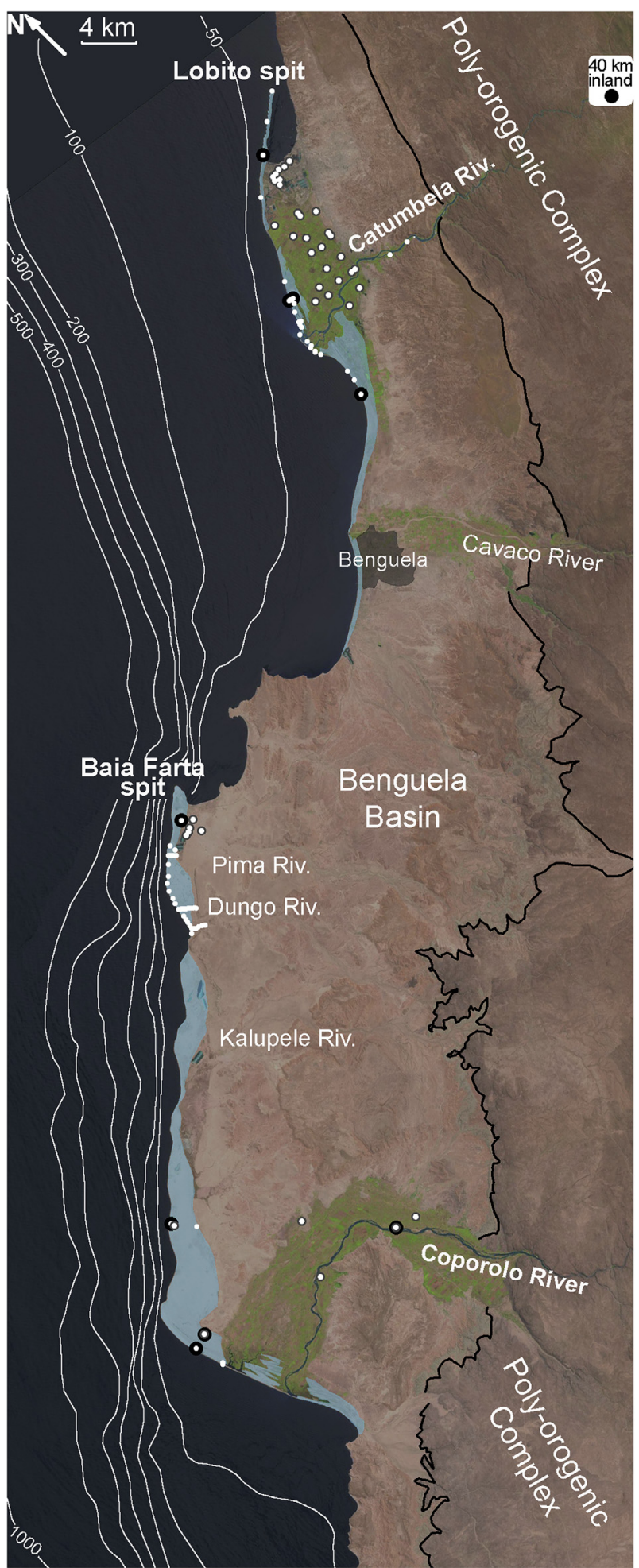

Fig. 2. The Lobito and Baía Farta sand spits north of the Catumbela and Coporolo river mouths. Sandbodies are highlighted in light blue. Location of sampling sites is indicated by small white dots. Samples selected for clay mineral and heavy mineral analysis are indicated by encircling grey lines and thick black lines, respectively. The location of a Catumbela sample collected $40 \mathrm{~km}$ inland (just analysed for heavy mineral assemblages) is indicated in Fig. 1. (For interpretation of the references to colour in this figure legend, the reader is referred to the web version of this article.)

wave-influenced asymmetric delta (Bhattacharya and Giosan, 2003; Anthony, 2015), being longer to the north (c. $19 \mathrm{~km}$ ) than to the south (c. $9 \mathrm{~km}$ ) and displaying a wider, more amalgamated, sand-dominated beach ridge system with minor lagoon deposits in its updrift part, contrasting with its downdrift part with sand bars separated by wider floodplain or fine-grained lagoonal units. The $5 \mathrm{~km}$-long Lobito sand spit constitutes the downdrift termination of the Catumbela deltaic system. The presence of the sand spits and beach-ridge systems to the north of major regional rivers and the asymmetry of the wave-dominated deltas demonstrate the importance of the northward longshore transport for coastal morphology.

\section{Methods}

\subsection{Sediment sampling}

Sediment samples were collected from beaches, river beds, salt marshes and small lagoons (58 samples in the CatumbelaLobito system; 50 samples in the Coporolo-Baía Farta system) and from boreholes drilled in the strandplain and floodplain associated with the two spit systems (25 samples in the Catumbela-Lobito system; 14 samples in Coporolo-Baía Farta system). Beach sediments were collected during low tide from the lower part of the beach face. Stream sediments are from different positions of channel bars. Boreholes were drilled with an Edelman hand auger with extension rods that allowed up to $6 \mathrm{~m}$ of perforation depth or until the water table was reached, with a sampling interval of $\sim 10 \mathrm{~cm}$. Samples were retrieved from homogeneous sedimentary units to ensure that the analyses were conducted on sediment representative of discrete sedimentological events.

\subsection{Sediment analysis}

Grain-size analyses of all samples were performed by laser diffraction and sieving. The results from both methods were adapted to a scale with $1 / 2 \varphi$ increments and, when necessary, merged to obtain bulk grain-size distribution curves using the SLCombo application (Dinis and Castilho, 2012). Modal sizes are referred to the finer limit of the grain-size-class for a $1 / 2 \varphi$ sizeclass interval. Statistical parameters were determined by the method of moments (after Krumbein and Pettijohn, 1938; and Friedman, 1979). In order to limit the effect of long tails with minor size-class proportions the $1 / 2 \varphi$ size-classes representing less than $0.1 \%$ were not considered in the numeric determination of the statistical parameters.

Heavy minerals were separated from the fine to very fine sand fraction of 10 samples using sodium polytungstate, and then mounted in Canada balsam on glass slides. The required amount of heavy minerals to fill an area of $25 \times 30 \mathrm{~mm}$ of each slide without grain overlap was obtained using a micro-splitter. On average, from about 300 particles identified on each sample (or slide) one third (100 particles) corresponds to transparent minerals, being the remaining grains opaque minerals or alterites. All these particles were counted using a petrographic microscope according to the ribbon method (Mange and Maurer, 1992).

The clay mineralogy was determined in 38 samples (26 from the Catumbela-Lobito system; 12 from the Coporolo-Baía Farta system) that contain significant amounts of silt-clay particles. The fraction finer than $2 \mu \mathrm{m}$ was separated by centrifugation according to Stokes' Law. The mineralogical analysis was performed on oriented mounts by X-ray diffraction (XRD) using a Philips PW 3710 equipment, with $\mathrm{Cu} \mathrm{K} \alpha$ radiation. A semi-quantitative evaluation of mineral proportions was obtained from distinctive XRD peak areas (Moore and Reynolds, 1997; Kahle et al., 2002). Peak areas were weighted by Schultz (1964) empirical factors. 


\section{Sand spit systems characterization}

\subsection{Grain-size distributions of depositional units}

On the basis of sediment grain-size distributions, four sediment types can be broadly distinguished in the Coporolo-Baía Farta and Catumbela-Lobito sectors (Figs. 3 and 4). These are: (1) beach and sand spit, (2) coastal lagoon, (3) fluvial channel and (4) floodplain and floodplain lakes. Aeolian deposits were not identified. Visual comparison of their grain-size distributions is applied to interpret former environmental setting for the borehole samples collected in the two sand spit systems.

\subsubsection{Beach and sand spit}

Beach sands from the Coporolo-Baía Farta and CatumbelaLobito systems are very coarse to medium grained, with modal sizes ranging between $0.25 \mathrm{~mm}(2 \varphi)$ and $1.0 \mathrm{~mm}(0 \varphi)$. Most size distributions are unimodal, moderately to well sorted and broadly symmetrical. Bimodal samples in present day beaches were observed near the Coporolo river mouth and in locations under the influence of groynes in the Lobito spit. Older beach sands collected in the strandplains are similar to the modern beach, but samples collected between beach ridges usually yield higher amounts of clay and silt and are frequently bimodal. The delta plain south of the Catumbela channel is composed almost exclusively of amalgamated beach units. Beach sands are intercalated with floodplain and lagoonal sediments along the northern flank of the delta.

\subsubsection{Coastal lagoon}

Two types of sediment can be considered within this major group. The first type is associated with wider low-energy environments in back-barrier settings and usually includes significant amounts of silt-clay particles. The sand-mud deposits exposed during low tide in the Lobito region constitute the most extensive present-day lagoonal unit of this type. The grain-size distributions are quite variable. Near the lagoonal outlets and at the contact with
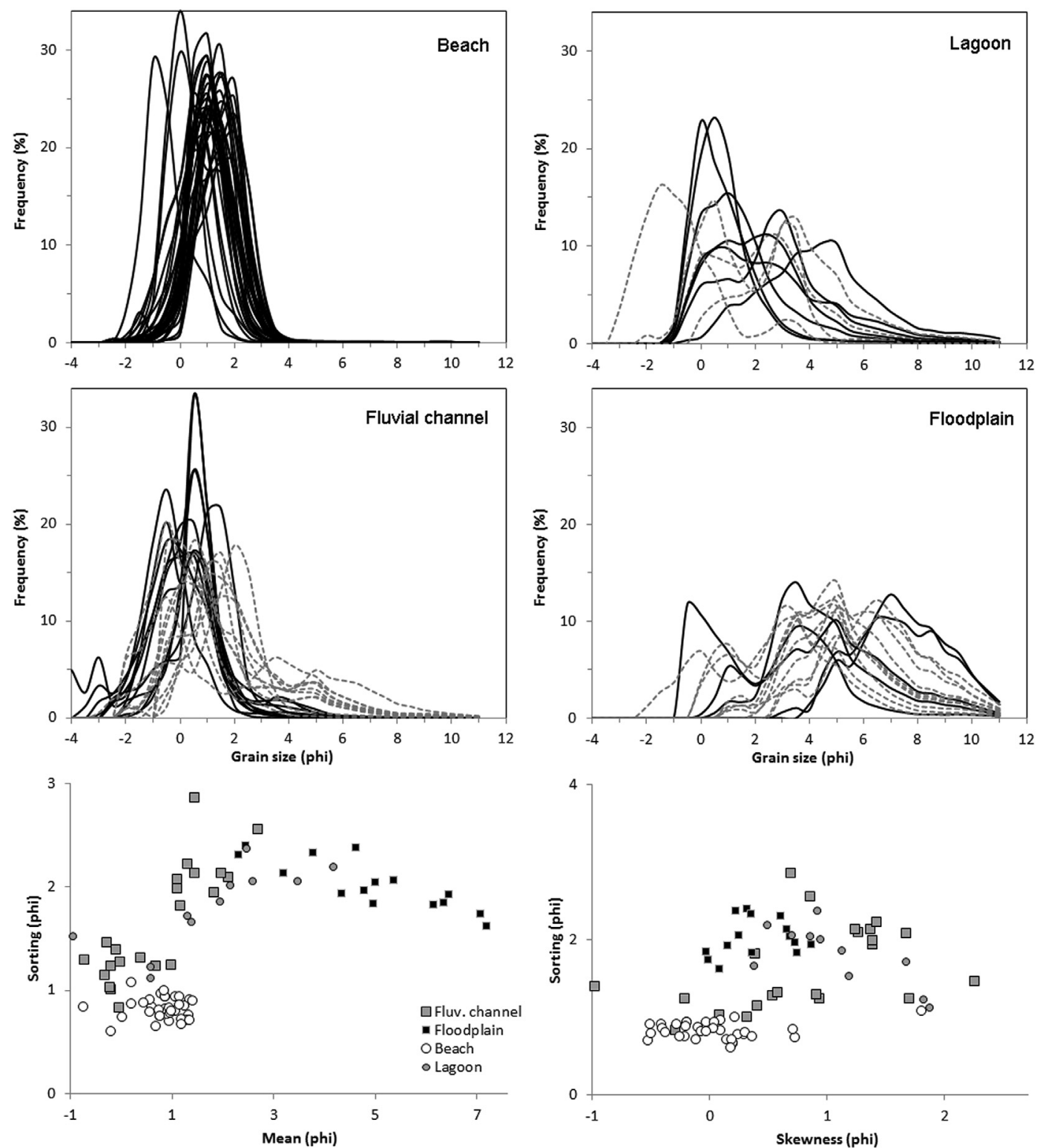

Fig. 3. Grain-size distribution curves and plots of statistical parameters for Catumbela-Lobito samples. 

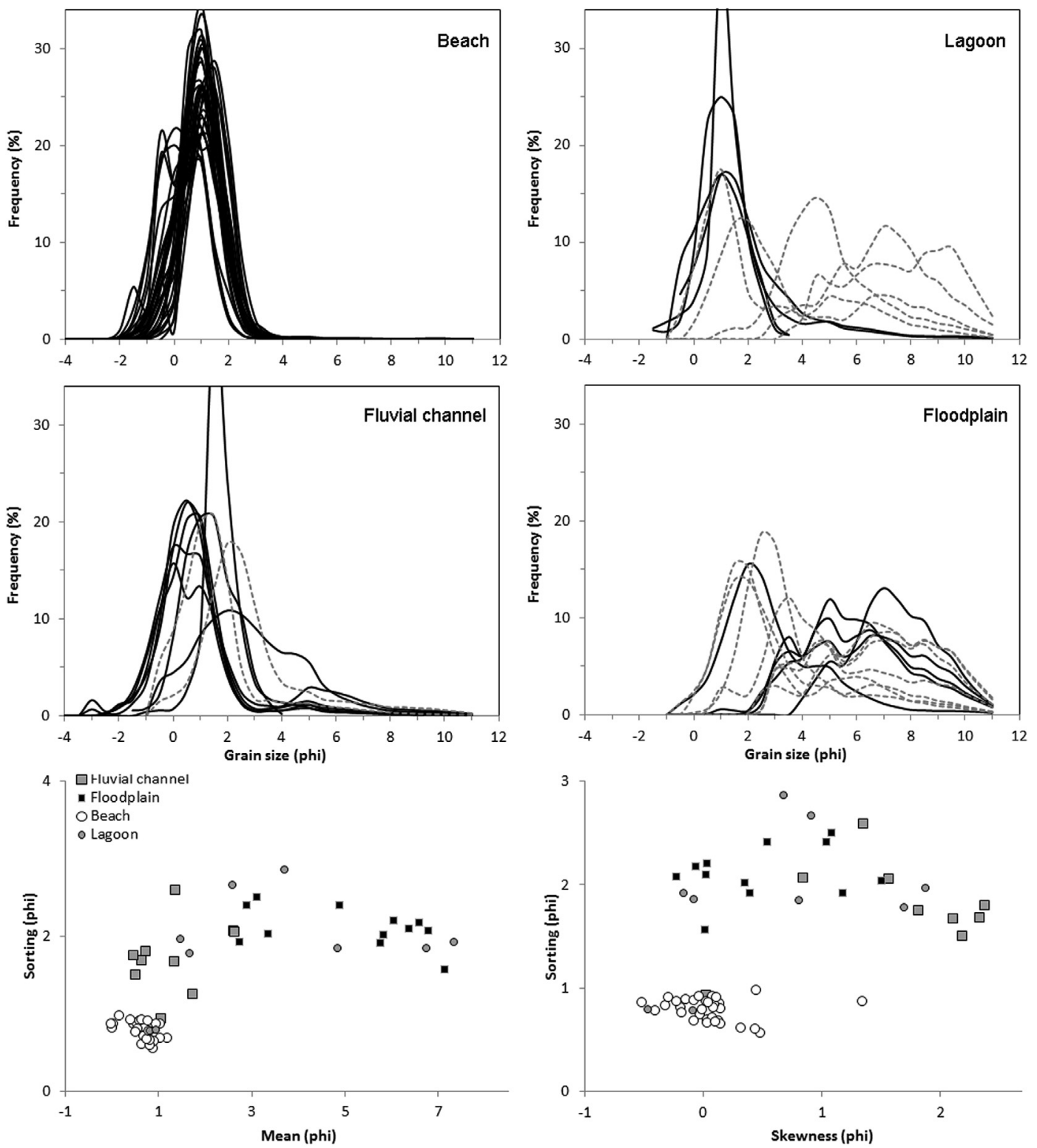

Fig. 4. Grain-size distribution curves and plots of statistical parameters for Coporolo-Baía Farta samples.

the beach, the lagoon deposits contain only minor amounts of silt-clay particles being characterized by a sand population similar to the adjacent beach. Further inland the size-distributions are characterized by a higher proportion of clay-to fine sand-sized particles that may be dominant. The modal size ranges between $0.31 \mathrm{~mm}(5 \varphi)$ and $0.177 \mathrm{~mm}(2.5 \varphi)$, becoming finer toward the centre of the lagoon.

The second type is related to littoral lakes up to $500 \mathrm{~m}$ long that develop in troughs aligned with the beach ridges or coinciding with truncation surfaces in the strandplain. These lakes are generally isolated from the fluvial channel and the connection with the sea occurs only occasionally. The sediment from these small lakes broadly resembles the evolving strandplain sandy units but usually contains a significant proportion of clay to fine sand.

Boreholes drilled in the Catumbela-Lobito and Baía Farta regions showed lagoon deposits covered by fluvial-channel and floodplain deposits. The size distributions are quite variable in both Catumbela and Coporolo systems, ranging from clay-dominated (modal size $1.4 \mu \mathrm{m} ; 9.5 \varphi$ ) to sand-dominated (modal size $1.4 \mathrm{~mm}$; $0.5 \varphi$ ), with coarser grain-size near small fluvial valleys that drain the costal sectors and at the contact with beach units.

\subsubsection{Fluvial channel}

Samples from present-day fluvial channels of the Catumbela and Coporolo systems are composed of very coarse to medium sand, with modal sizes ranging between $0.355 \mathrm{~mm}(1.5 \varphi)$ and $1.4 \mathrm{~mm}(-0.5 \varphi)$. These sediments are distinguished from beach deposits by the presence of a subsidiary population of very-fine sand to coarse silt (modal size 0.031-0.125 mm; 5-3 $\varphi$ ).

Samples collected in boreholes contain higher amounts of clay and silt (c. $10-20 \%$ ) than in active channels $(<4 \%$ ), which is attributed to possible sampling in transitional sectors between channel and floodplain deposits and/or post-depositional incorporation of fines. Despite this feature, the grain-size distributions of active and buried channels are similar.

\subsubsection{Floodplain and floodplain lake}

Two types of floodplain deposits can be distinguished by their 
grain-size distribution. The first type is composed almost exclusively of silt and clay (modal size $<11 \mu \mathrm{m} ; 6.5-7 \varphi$ ). In the Catumbela floodplain part of these lakes were found to be genetically linked with sinuous abandoned channels. A second, and most common type, is usually bimodal with a dominant population of very fine sand to silt (modal sizes $0.031-0.088 \mathrm{~mm} ; 5-3.5 \varphi$ ) and subordinate medium to coarse sand that resembles the dominant population of fluvial channel deposits.

Except for the boreholes drilled in the strandplains south of the Catumbela channel and in Baía Farta, floodplain and floodplain lake sediments are the most common in the boreholes. Their grain-size is hardly distinguished from that of surface units.

\subsection{Heavy mineral assemblages}

The heavy-mineral assemblages presented here consider only the translucent minerals. The Catumbela-Lobito system (represented by 5 samples) shows a heavy-mineral spectrum dominated by epidote (27-69\%, averaging $45 \%$ ), amphibole (12-32\%, averaging $27 \%$, zircon (2-36\%, averaging $15 \%$ ) and pyroxene $(2-25 \%$, averaging $15 \%$ ), followed by titanite (1-10\%, averaging $4 \%$ ) and minor quantities of staurolite, andalusite and tourmaline. The Coporolo-Baía Farta system (5 samples) reveals a heavy-mineral spectrum dominated by epidote (35-81\%, averaging $61 \%$ ) and amphibole (16-44\%, averaging $27 \%$ ), in association with secondary amounts of zircon, titanite, pyroxene and andalusite (Fig. 5). Amphibole-rich samples in the Catumbela-Lobito system are dominated by brown amphibole, whereas in the Coporolo-Baía Farta system green amphibole frequently prevails. Zircon grains from the Catumbela-Lobito system are commonly euhedral and relatively large $(\sim 100 \mu \mathrm{m})$.

\subsection{Clay-mineral assemblages}

Kaolinite, mica-illite, smectite and illite-smectite mixed-layer clays occur in variable amounts in different regions and depositional units (Fig. 6). Kaolinite is more abundant in Catumbela $(\sim 24-87 \%)$ than Coporolo $(\sim 4-41 \%)$ fluvial units. Fine-grained floodplain deposits from the Catumbela River are strongly enriched in kaolinite $(\sim 82-87 \%)$ relative to coarser floodplain and fluvial channel sediments ( 24-76\%). Lagoon deposits yield variable amounts of kaolinite $(\sim 0-70 \%$ in Catumbela; $\sim 1-55 \%$ in Coporolo).

Mica-illite is invariably present. Its proportion in the Catumbela system is generally higher in lagoonal units $(\sim 30-100 \%)$ than in fluvial sediments ( 13-57\%). Fine grained floodplain deposits from the Catumbela system are generally poorer in mica-illite ( 13-18\%) than the coarser floodplain and fluvial channel units (8-58\%, usually $>\sim 20 \%$ ). Mica-illite abundance is more variable in lagoon $(\sim 25-78 \%)$ than fluvial deposits ( $41-58 \%)$ of the Coporolo system.

Expansive clays (i.e. smectite and illite-smectite mixed-layers) occur occasionally in significant proportions in both fluvial and lagoonal sediments. Illite-smectite was found in floodplain and lagoon deposits from the Baía Farta region ( $32-74 \%)$. The remaining lagoon deposits associated with Coporolo and Catumbela rivers yield minor amounts of smectite. Fine-grained floodplain deposits from the Catumbela-Lobito region lack smectite.

\section{Sediment supply and sand spit evolution}

\subsection{Sediment sources and dispersal}

The spatial relation of the strandplains and sand spits with major regional rivers indicate that an important part of the sediment in transit along the costal stretches has a local fluvial origin. The Catumbela and Coporolo rivers are the only regional rivers with

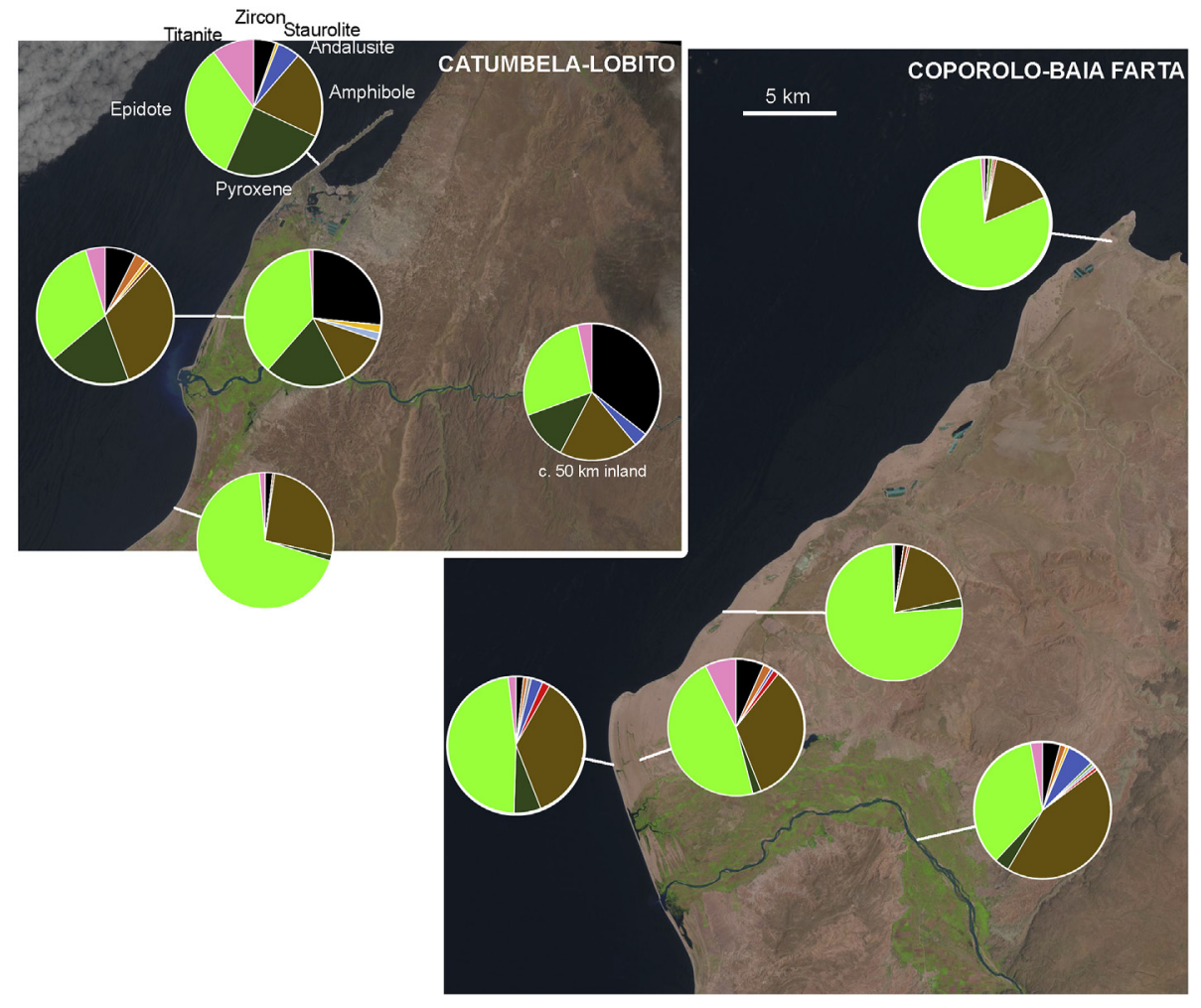

Fig. 5. Heavy mineral assemblages in Catumbela-Lobito and Coporolo-Baía Farta coastal stretches. 


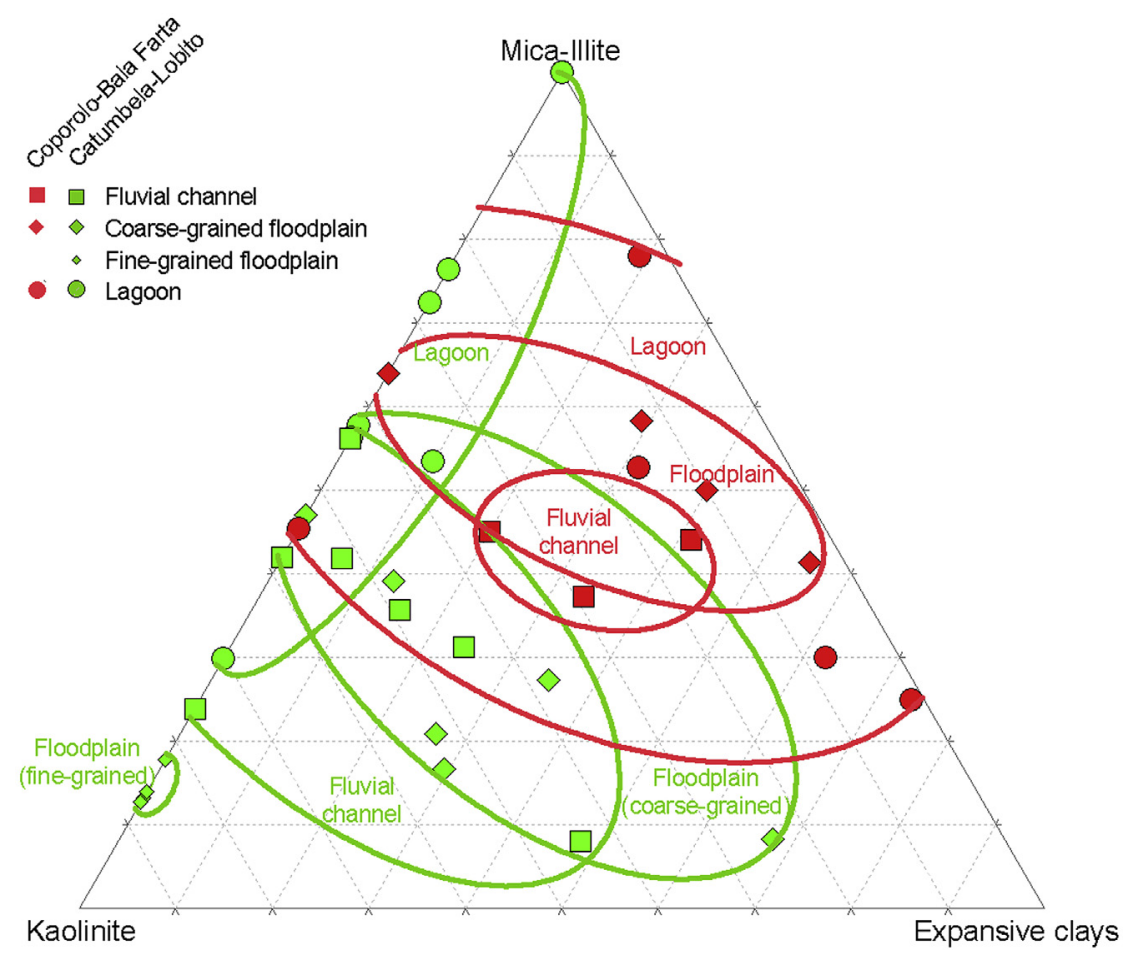

Fig. 6. Clay mineralogy of Coporolo-Baía Farta and Catumbela-Lobito systems.

perennial discharge. Their catchments extend across the Benguela Basin with Meso-Cenozoic sedimentary units, the coastal polyorogenic igneous and metamorphic complex and, in particular, the mainly Eburnean crystalline units further inland (Fig. 1). Based on regional orography and the spatial distribution of rainfall (Dinis et al., 2013), it is expected that the highest sediment yields from the Coporolo and Catumbela drainage basins are generated in a belt some $50-100 \mathrm{~km}$ from the shoreline, where the Eburnean rocks dominate. Fluvial flow in smaller streams along the coast occurs just occasionally and hardly reaches the shoreline, but may provide supplementary sediment to the coast (Carvalho, 1963). Previous works on the SW Africa coastal region point to a longshore transport of sediment supplied by the Orange River for at least $1750 \mathrm{~km}$, reaching the Tombua region in SW Angola (Garzanti et al., 2014, 2015). The Orange River's contribution decreases northward as its sediments are diluted by detritus derived from the coastal cliffs or supplied by the Angolan rivers with Atlantic drainage. Given the absence of relevant active wind accumulations north of the Curoca River (river mouth at $15.7^{\circ} \mathrm{S}$, some $340 \mathrm{~km}$ to the south of the study area), atmospheric transport is considered to be limited in current times. The grain-size distribution of the samples collected along the beach-ridge sequences does not reveal the presence of aeolian sediments (Figs. 3 and 4), indicating that the strandplains were exclusively built by wave-induced processes.

Beach sands in coastal Benguela are a mixture of fluvial bedload delivered by major regional rivers (mostly Coporolo and Catumbela) with background sediment produced by erosion of rock units exposed close to or along the shore and transported by local rivers and littoral currents. Heavy-mineral assemblages allow the discrimination of these diverse sources. Widespread epidote abundance reflects the exposure of metamorphic rocks, including epidotites, in the poly-orogenic complex that constitutes the basement of the Benguela Basin (Carvalho, 1983, 1984). Sandy shorelines form principally on the downdrift side of major river outlets, where fluvial sediment mixes and is diluted by sand transported by northward littoral currents. The contrasting geology of the Catumbela and Coporolo catchments explains some differences in the heavy-mineral assemblages carried by these two rivers. Zircon may be ultimately derived from magmatic units associated with the metasomatic porphyritic granites (Quibalatype granites; Silva, 2005) or acid porphyries and extrusive rocks that are widespread in the Catumbela River catchment (Carvalho, 1980, 1984, Table 1). The calc-alkaline "regional granites", which are dominant in the Coporolo catchment (Carvalho, 1980, 1984, Table 1), account for the abundance of amphibole in sediments of the Coporolo River.

The distal stretch of the Coporolo River is characterized by a $\sim 5 \mathrm{~km}$-wide and $\sim 25 \mathrm{~km}$-long alluvial plain and no delta protrusion. The retention of sediment in this wide alluvial plain, the steep slopes of the submerged area around the Coporolo outlet and the location of the outlet in a short coastal stretch (striking NNW-SSE) on the updrift flank of a curvature to a sector where strong unidirectional longshore transport should prevail (striking NE-SW) explain the complete absence of a delta bulge associated with the Coporolo River. Regarding the Catumbela delta, the combined coastline and wave orientation south of the outlet promotes a local southward drift and a divergent transport at the Catumbela deltaic bulge. This divergent transport is reflected in the relatively symmetric pattern of variation of several grain-size parameters (such as modal size, mean and sorting) and the proportions of size-fractions north and south of the Catumbela river mouth (Fig. 7). Excepting the absence of a distinct fine-grained population, the grain-size distribution of beach deposits resembles most Catumbela fluvial channel sediments, reinforcing the possibility that sand in the Catumbela-Lobito stretch is mainly derived from the Catumbela River bedload. In wave-dominated deltas the reworking of mouth bars or previous delta lobes is responsible for the mixture of the fluvial load with coastal deposits (Wright, 1977; Sabatier et al., 2009; Anthony, 2015). Local concentration of dense and ultradense minerals (e.g. zircon) in placer lags and their depletion in adjacent deposits is a consequence of wave-induced hydraulicsorting. 
Table 1

Proportion of distinct geological units within major rivers catchments from Benguela region.

\begin{tabular}{|c|c|c|c|c|c|}
\hline & Coporolo & Calupele & Dungo & Cavaco & Catumbela \\
\hline Miocene-Holocene (clastic sediments and sedimentary rocks) & 0.2 & 9.7 & 11.1 & 1.1 & 0.1 \\
\hline Cretaceous-Miocene (Benguela Basin sedimentary rocks & 0.5 & 27.8 & 24.1 & 3.4 & 0.7 \\
\hline Phanerozoic igneous (porphyries, kimberlites, alkaline and basic complexes) & 1.1 & & & 0.0 & 3.5 \\
\hline "Gabbro-anorthosite complex" and other Precambrian mafic rocks & 0.3 & & & & 0.1 \\
\hline Eburnean "Regional granites" (equigranular, calc-alkaline) & 71.5 & & 12.6 & 70.1 & 34.6 \\
\hline Eburnean "Quibala-type” granites (porphyritic, calc-alkaline) & 9.4 & & & 18.3 & 36.5 \\
\hline Eburnean and ante-Eburnean porphyries and extrusive rocks & 2.7 & & & & 14.3 \\
\hline Eburnean and ante-Eburnean metasediments & 1.0 & & & 0.0 & 0.3 \\
\hline Poly-orogenic complex (diverse metamorphic and igneous rocks) & 13.2 & 62.5 & 52.2 & 7.0 & 10.0 \\
\hline
\end{tabular}

The clay-mineral assemblages also reflect supply from distinct source areas. The semi-arid climate of coastal Benguela is not favourable for kaolinite formation (Chamley, 1989; Velde, 1995). Given the progressive inland increase in humidity, weathering intensity increases eastwards and sediment carried from inland Angola by the Catumbela and Coporolo rivers is expected to be enriched in kaolinite, in particular when sourced from longexposed flat areas, such as the extensive platforms found throughout Angola. Kaolinite abundance in surface sediments of the southeast Atlantic increases sharply approximately at the latitude of Benguela (Petschick et al., 1996), suggesting that the Catumbela and Coporolo river mouths mark an important change in the clay mineralogy supplied to SE Atlantic Ocean. Mica-illite in littoral sediments from Benguela region may result from the earlier stages of weathering and erosion of basement rocks in the Angola hinterland or be derived from southern Africa and transported northward by marine currents and wind (Diester-Haass et al., 1990; Petschick et al., 1996; Robert et al., 2005). Soils from the Benguela Basin are rich in expansive clays (e.g. smectite), whereas the zone to the east display more illite and kaolinite (Furtado, 1967). River catchments almost entirely comprised within the Benguela Basin are thus expected to contribute large amounts of expansive clays.
Variable kaolinite/mica-illite ratio and smectite content in lagoonal and fluvial deposits (Fig. 6) suggest distinct sediment sources. The greater abundance of mica-illite in the outer parts of the lagoon enclosed by the Lobito spit is compatible with some supply by littoral currents. The proportions of mica-illite tend to be higher in coarser lagoonal sediments, which are usually enriched in a sand population that mimics the size distribution of adjacent beach deposits (Fig. 8). Regarding floodplain deposits, the enrichment in kaolinite and absence of smectite in finer grained deposits of the Catumbela delta plain indicate provenance from the Angola hinterland. During major floods triggered by intense rainfall in the hinterland, suspended load is not entirely dispersed offshore, but partly trapped within the coastal zone in the small floodplain lakes of the Benguela delta. It is assumed that most sediment reaching the small lakes within the floodplain is delivered during major floods. Conversely, the abundance of smectite in small lagoon deposits far from the Coporolo river mouth and in coarse floodplain deposits from the Catumbela alluvial plain indicates major contribution by small streams draining the littoral region.

\subsection{Implications for sand-spit configuration and evolution}

The coastal morphologies around the Coporolo and Catumbela
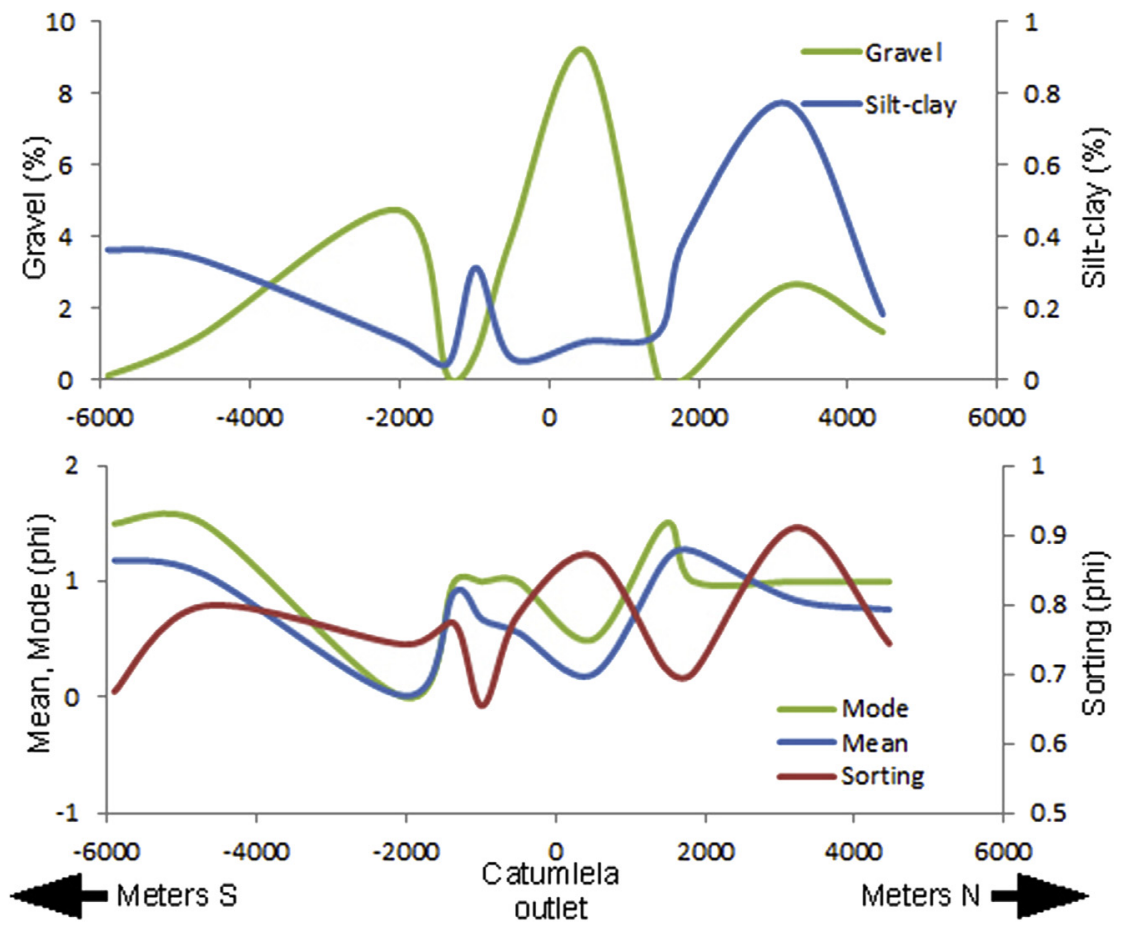

Fig. 7. Pattern of variation of grain-size parameters in beach sediments near the Catumbela outlet. 

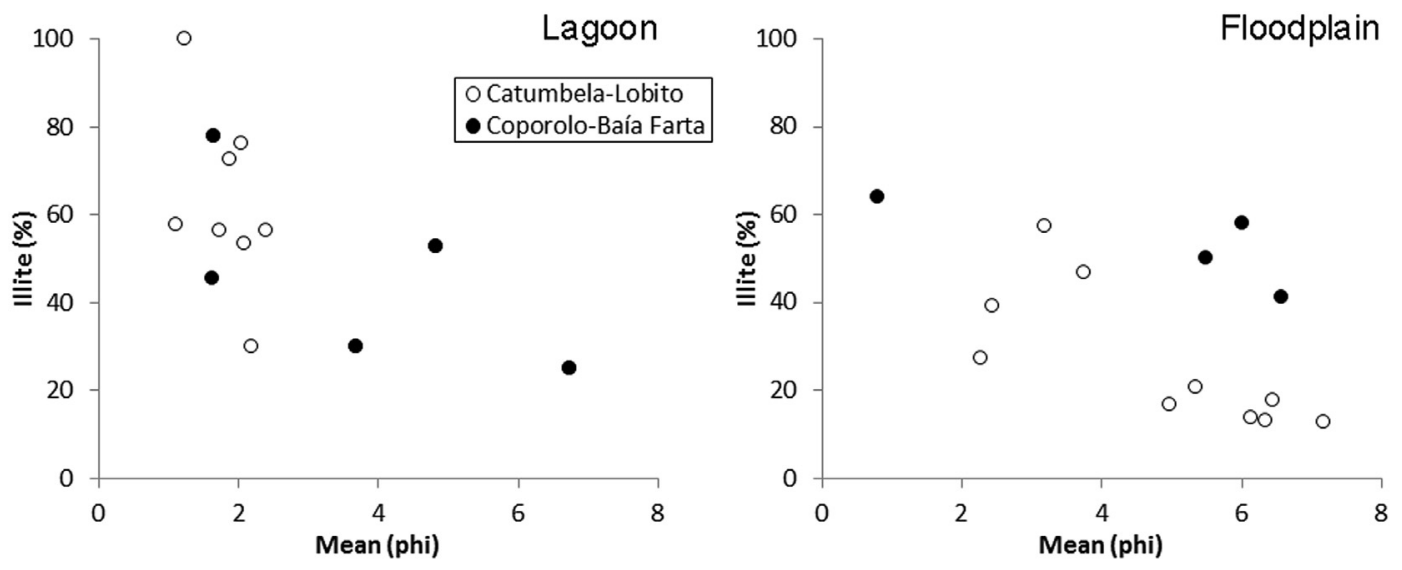

Fig. 8. Relation between mean grain-size and mica-illite abundance in lagoon and floodplain deposits.

mouths are sharply distinct, reflecting distinct physical processes. The configuration of the adjoining strandplains and sand spits is largely conditioned by littoral orography, wave orientation relative to the coast, and sediment supply and dispersal in each coastal sector. A conceptual synthesis of the sources and dispersal vectors influencing the evolution of coastal sediment accumulations is presented in Fig. 9.

A substantial part of the bedload and suspended load supplied by the Catumbela River is transported longshore by wave-induced currents promoting beach progradation and formation of coastal landforms, including the Lobito sand spit. The groyne effect imposed by the fluvial jet (Komar, 1973; Dominguez, 1996; Bhattacharya and Giosan, 2003; Anthony, 2015) explains the asymmetry of the Catumbela delta with amalgamated beach ridges along its southern flank and beach ridges intercalated with mudrich deposits along its northern flank. The Lobito spit is a long and narrow linear accumulation (length/width $=13$ ) attached to a beach ridge that lengthened rapidly during the 19th and early 20th centuries (Abecassis, 1958). Its growth was limited later on by a succession of groynes created in mid-20th century to reduce the siltation of the Lobito bay and prevent coastal erosion in the highly urbanized sand spit. Without these structures, the sheltered Lobito
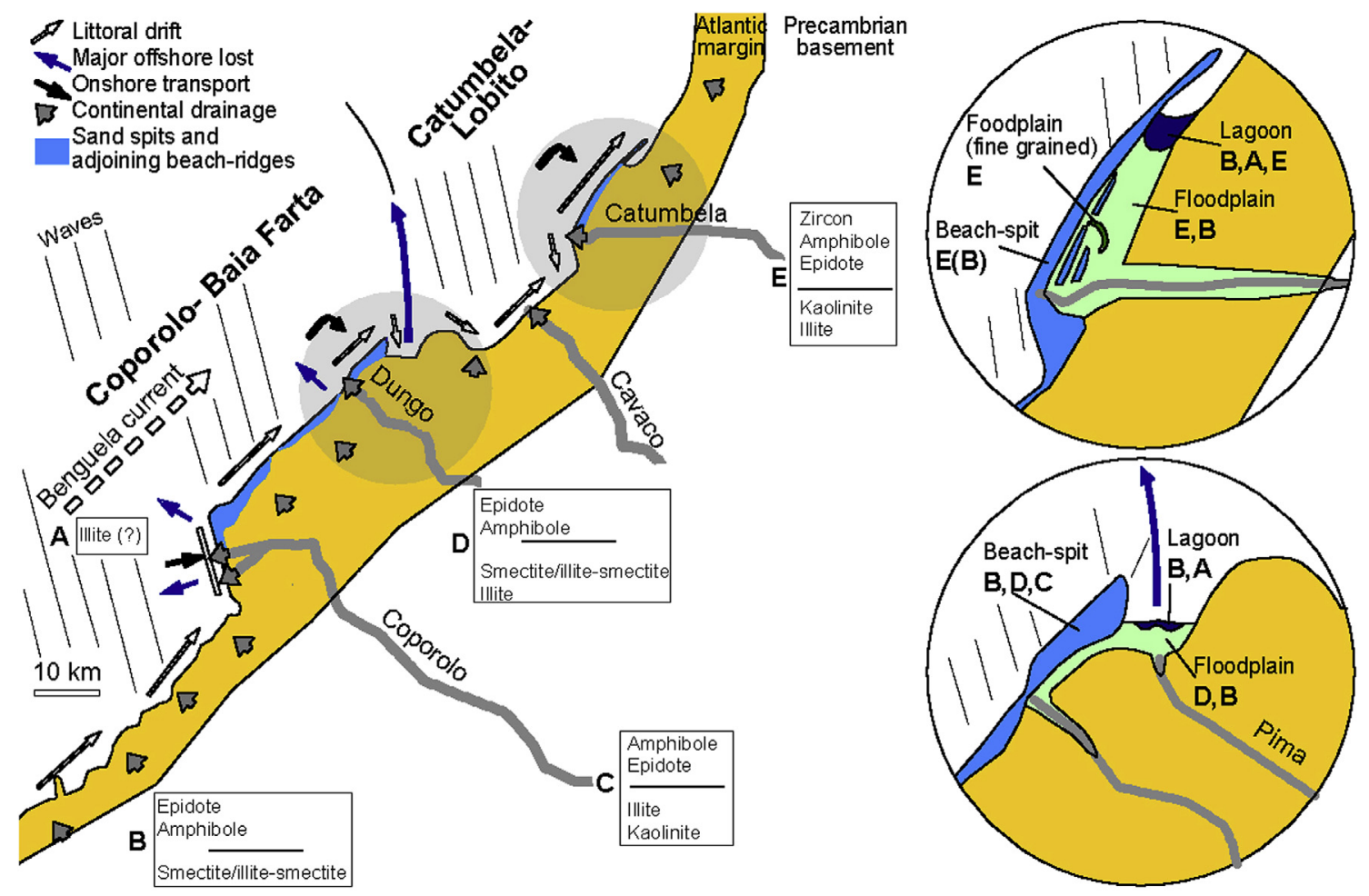

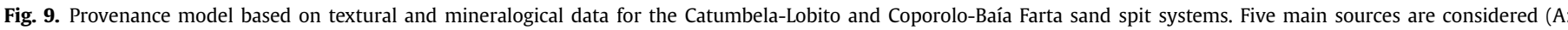

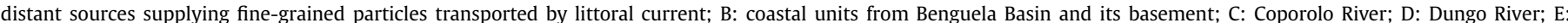

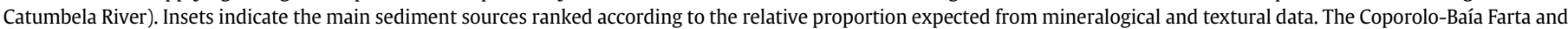

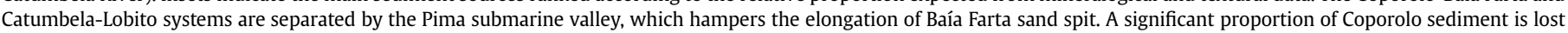

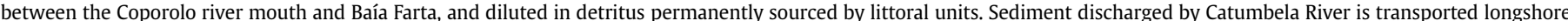

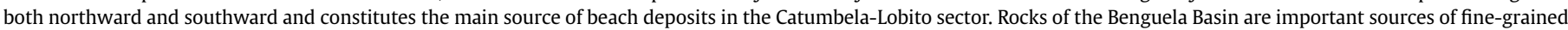
sediment. 
bay should be progressively filled by sediments supplied by the Catumbela River and littoral streams. The succession of groynes and current dredging of the bay prevent siltation and stabilizes the sand spit. Hence, the final stages of evolution when the bay becomes progressively narrower as the spit expands towards the mainland, as proposed by Dan et al. (2011), were not reached.

The geomorphic setting of the Coporolo River outlet does not allow the development of a delta bulge. Coporolo bedload along with sediment derived from the eroding coast in the south is carried NE-ward by strong longshore currents and accumulates in a strandplain with several generations of amalgamated sandy beach ridges separated by truncation surfaces. The Baía Farta spit contrasts with the Lobito spit by its limited length (c. $1.5 \mathrm{~km})$ and low length/width ratio (c. 1.5). The spit reveals no signs of progressive elongation or migration landward and the available charts and aerial images show the spit with approximately unmodified morphology since the 1950s. This stability is probably influenced by the presence of a steep submarine valley aligned with the Pima River that may capture the longshore drift and thus block the northward elongation of the spit (Figs. 2 and 9). Wave refraction in the open bay protected by the short spit promotes sand accumulation along its inner side (i.e. SE), explaining its relatively large width (Fig. 9). As for the Lobito system, local sources supply important amounts of sediment to the bay. Natural siltation of the bay should not occur because sediment tends to be conveyed offshore through the Pima submarine valley (Fig. 9).

\section{Conclusions}

The sand spits and strandplain systems of the littoral Benguela of SW Angola are formed mainly by sediment delivered by regional rivers and carried northward by longshore drift. The combination of strong obliquely impinging waves and coastal morphology promotes persistent longshore currents carrying sediment northward of the Coporolo river mouth. Part of the beach sediment along the Coporolo-Baía Farta sector, however, may also be derived from eroding coasts and local streams. Although a strong northward drift characterizes the Atlantic coast of Angola, the variable heavymineral assemblages in the Catumbela-Lobito and Coporolo-Baía Farta systems indicate distinct sand sources and limited connectivity between coastal stretches. The asymmetric Catumbela delta is also strongly influenced by the regional longshore currents, but some divergent drift occurs in the coastal stretches north (NNWward) and south (SSE-ward) of the river mouth. Widely variable clay mineralogy also points to distinct sediment sources. Sediment derived from wetter inland areas of Angola is enriched in kaolinite, whereas sedimentary rocks of the Benguela Basin supply mainly expansive clays. In the Catumbela floodplain, finer-grained deposits are enriched in kaolinite and depleted in smectite (or illite-smectite mixed-layers), suggesting that they were generated during major floods and derived from the hinterland. Conversely, coarser-grained fluvial deposits usually contain significant proportions of smectite and lower kaolinite/mica-illite ratios, reflecting a higher contribution of sediment derived more locally within the Benguela Basin. The textural data and combined clay- and heavy-mineral assemblages indicate that despite the association of the sand spits with major regional rivers to the south (Coporolo and Catumbela) an important proportion of the sediment in coastal accumulations is derived from local littoral sources.

\section{Acknowledgements}

The authors are grateful for the field support provided by Margarida Ventura and Carlos Ribeiro from the Instituto Superior Politécnico Tundavala (Angola). This study was supported by the
FCT (Portuguese National Board of Scientific Research) through the MARE (Marine and Environmental Sciences Centre) (UID/MAR/ 04292/2013) Strategic Program. V. Mantas is acknowledge for assistance in the analysis of the drainage basins. Two anonymous reviewers are thanked for their constructive comments and suggestions.

\section{References}

Abecassis, F.M., 1958. Les flèches de sable de la côte d'Angola. In: Laboratório Nacional de Engenharia Civil, Mém. 140.

Anthony, E.J., 2015. Wave influence in the construction, shaping and destruction of river deltas: a review. Mar. Geol. 361, 53-78.

Aslanian, D., Moulin, M., Olivet, J.L., Unternehr, P., Matias, L., Bache, F., Rabineau, M., Nouzé, H., Klingelhoefer, F., Contrucci, I., Labails, C., 2009. Brazilian and African passive margins of the Central Segment of the South Atlantic Ocean: Kinematic constraints. Tectonophysics 468, 98-112.

Bhattacharya, J.P., Giosan, L., 2003. Wave-influenced deltas: geomorphological implications for facies reconstruction. Sedimentology 50, 187-210.

Buta-Neto, A., Tavares, T.S., Quesne, D., Guiraud, M., Meister, C., David, B., DuarteMorais, M.L., 2006. Synthèse préliminaire des travaux menés sur le bassin de Benguela (Sud d'Angola): Implications sédimentologiques et structurales. Afr. Geosci. Rev. 13, 239-250.

Campbell, T., 2005. Development of a conceptual morphosedimentary model for design of coastal restoration projects along the Louisiana coast. Journal of Coastal Research. Spec. Issue 44, 234-244.

Carvalho, G.S., 1963. Problemas de sedimentologia das praias do litoral de Angola: entre a foz do rio coporolo e o Lobito. Garcia Orta 11, 291-313.

Carvalho, H., 1980. Geologia de Angola, escala 1:1.000.000, folha 3. Laboratório Nacional de Investigação Cientifica e Tropical.

Carvalho, H., 1984. Estratigrafia do Precâmbrico de Angola. Garcia Orta 7, 1-66.

Carvalho, H., 1983. Notice explicative preliminaire sur la geologie de l'Angola. Garcia Orta $6,15-30$

Carvalho, H. de, Tassinari, C., Alves, P.H., Guimarães, F., Simões, M.C., 2000. Geochronological review of the Precambrian in western Angola: links with Brazil. J. Afr. Earth Sci. 31, 383-402.

Chaboureau, A.-C., Guillocheau, F, Robin, C., Rohais, S., Moulin, M., Aslanian, D. 2013. Paleogeographic evolution of the central segment of the South Atlantic during Early Cretaceous times: Paleotopographic and geodynamic implications. Tectonophysics 604, 191-223.

Chamley, H., 1989. Clay Mineralogy. Springer, Berlin.

Contrucci, I., Matias, L., Moulin, M., Géli, L., Klingelhofer, F., Nouzé, H., Aslanian, D., Olivet, J.L., Réhault, J.P., Sibuet, J.C., 2004. Deep structure of the West African continental margin (Congo, Zaïre, Angola), between $5^{\circ} \mathrm{S}$ and $8^{\circ} \mathrm{S}$, from reflection/refraction seismics and gravity data. Geophys. J. Int. 158, 529-553.

Dan, S., Walstra, D.J.R., Stive, M.J.F., Panin, N., 2011. Processes controlling the development of a river mouth spit. Mar. Geol. 280, 115-129.

Davis, R.A., Hayes, M.O., 1984. What is a wave-dominated coast? Mar. Geol. 60, 313-329.

de Waele, B., Johnson, S.P., Pisarevsky, S.A., 2008. Palaeoproterozoic to Neoproterozoic growth and evolution of the eastern Congo Craton: its role in the Rodinia puzzle. Precambrian Res. 160, 127-141.

Diester-Haass, L.D., Meyers, P.A., Rothe, P., 1990. Miocene history of the Benguela current and Antarctic ice volumes: evidence from rhythmic sedimentation and current growth across the Walvis Ridge (DSDP Sites 362-532). Paleoceanography $5,685-707$

Diester-Hass, L., Meyers, P.A., Vidal, L., 2002. The late Miocene onset of high productivity in the Benguela Current upwelling system as part of a global pattern. Mar. Geol. 180, 87-103.

Dinis, P.A., Castilho, A.M., 2012. Integrating sieving and laser data to obtain bulk grain-size distributions. J. Sediment. Res. 82, 747-754.

Dinis, P.A., Mantas, V., Andrade, P.S., Tonecas, J., Kapula, E., Pereira, A., Carvalho, F.S., 2013. Contribution of TRMM rainfall data to the study of natural systems and risk assessment. Cases of application in SW Angola. Estud. do Quat. 9, 25-35. Diniz, A.C., 2006. Características Mesológicas de Angola. IPAD, Lisboa.

Dominguez, J.M.L. 1996. The São Francisco strandplain: a paradigm for wavedominated deltas? In: Baptist, M., Jacobs, P. (Eds.), Geology of Siliciclastic Shelf Seas, Geological Soclety of London Spec. Publ. 117, pp. 217-231.

Friedman, G.M., 1979. Differences in the size distributions of populations of particles among sands of various origins. Sedimentology 26, 3-32.

Furtado, A.F.A.S., 1967. As argilas dos solos do distrito de Benguela. Garcia Orta 15, $567-576$.

Garzanti, E., Andò, S., Padoan, M., Vezzoli, G., Vermeesch, P., Lustrino, M., 2014. Ultra-long distance littoral transport of Orange sand and provenance of the Skeleton Coast Erg (Namibia). Mar. Geol. 357, 25-36.

Garzanti, E, Resentini, A., Andò, S, Vezzoli, G. Pereira, A, Vermeesch, P. 2015. Physical controls on sand composition and relative durability of detrital minerals during ultra-long distance littoral and aeolian transport (Namibia and southern Angola). Sedimentology 62, 971-996.

Giresse, P., Hoang, C.T., Kouyoumontzakis, G., 1984. Analysis of vertical movements deduced from a geochronological study of marine Pleistocene deposits, southern coast of Angola. J. Afr. Earth Sci. 2, 177-187. 
Guiraud, M., Buta-Neto, A., Quesne, D., 2010. Segmentation and differential post-rift uplift at the Angola margin as recorded by the transform - rifted Benguela and oblique-to-orthogonal-rifted Kwanza basins. Mar. Pet. Geol. 27, 1040-1068.

Hardman-Mountford, N.J., Richardson, A.J., Agenbag, J.J., Hagen, E., Nykjaer, L., Shillington, F.A., Villacastin, C., 2003. Ocean climate of the South East Atlantic observed from satellite data and wind models. Prog. Oceanogr. 59, 181-221.

Heilborn, M., Valeriano, C.M., Tassinari, C.C.G., Almeida, J., Tupinambá, M., Siga Jr., O., Trouw, R., 2008. Correlation of Neoproterozoic terranes between the Ribeira Belt, SE Brazil and its African counterpart: comparative tectonic evolution and open questions. In: Pankhurst, R.J., Trouw, R.A.J., Brito Neves, B.B., Wit, M.J. (Eds.), West Gondwana: Pre-cenozoic Correlations across the South Atlantic Region, Geological Society, London, Spec. Publ. 294, pp. 211-237.

Jiménez, J., Sánchez-Arcilla, A., 2004. A long-term (decadal scale) evolution model for microtidal barrier systems. Coast. Eng. 51,749-51,764.

Kahle, M., Kleber, M., Jahn, R., 2002. Review of XRD-based quantitative analyses of clay minerals in soils: the suitability of mineral intensity factors. Geoderma 109, 191-205.

Komar, P.D., 1973. Computer models of delta growth due to sediment input from rivers and longshore transport. Geol. Soc. Am. Bull. 84, 2217-2226.

Krumbein, W.C., Pettijohn, F.J., 1938. Manual of Sedimentary Petrography. AppletonCentury-Crofts, New York.

Mange, M.A., Maurer, H.F.W., 1992. Heavy Minerals in Colour. Chapman and Hall, London.

Marzoli, A., Melluso, L., Morra, V., Renne, P.R., Sgrosso, I., D'Antonio, M., Duarte, L., Morais, E.A.A., Ricci, G., 1999. Geochronology and petrology of Cretaceous basaltic magmatism in the Kwanza basin (western Angola), and relationship with the Prana-Etendeka continental flood basalt province. J. Geodyn. 28, $341-356$.

Moore, D., Reynolds, R., 1997. X-Ray-Diffraction and the Identification and Analysis of Clay-Minerals. Oxford University Press, New York.

Moulin, M., Aslanian, D., Olivet, J.-L., Contrucci, I., Matias, L., Géli, L., Klingelhoefer, F., Nouzé, H., Réhault, J.-P., Unternehr, P., 2005. Geological constraints on the evolution of the Angolan margin based on reflection and refraction seismic data (ZaïAngo project). Geophys. J. Int. 162, 793-810.

Nienhuis, J.H., Ashton, A.D., Roos, P.C., Hulscher, S.J.M.H., Giosan, L., 2013. Wave reworking of abandoned deltas. Geophys. Res. Lett. 40, 5899-5903.

Otvos, E.G., 2000. Beach ridges-definitions and significance. Geomorphology 32. 83-108.

Peel, M.C., Finlayson, B.L., Mcmahon, T.A., 2007. Updated world map of the KoppenGeiger climate classification. Hydro. Earth Syst. Sci. 11, 1633-1644.

Penland, S., Boyd, R., Suter, J.R., 1988. Transgressive depositional systems of the Mississippi delta plain: a model for barrier shoreline and shelf sand development. J. Sediment. Petrol. 58, 932-949.

Pereira, E., Tassinari, C.C.G., Rodrigues, J.F., Van-Dúnem, M.V., 2011. New data on the deposition age of the volcano-sedimentary Chela Group and its Eburnean basement: implications to post-Eburnean crustal evolution of the SW of Angola. Comun. Geol. 98, 29-40.

Petschick, R., Kuhn, G., Gingele, F., 1996. Clay mineral distribution in surface sediments of the South Atlantic: sources, transport, and relation to oceanography Mar. Geol. 130, 203-230.

Quesne, D., Buta-Neto, A., Benard, D., Guiraud, G., 2009. Distribuition of Albian clastic deposits in the Benguela basin (Angola): evidence of a Benguela paleocorrent? Bull. la Société Géol. Fr. 180, 117-129.

Robert, C., Diester-Haass, L., Paturel, J., 2005. Clay mineral assemblages, siliciclastic input and paleoproductivity at ODP Site 1085 off southwest Africa: a late Miocene -early Pliocene history of Orange River discharges and Benguela Current activity, and their relation to global sea level change. Mar. Geol. 216, 221-238.

Rodriguez, A.B., Hamilton, M.D., Andersen, J.B., 2000. Facies and evolution of the modern Brazos Delta, Texas: wave versus flood influence. J. Sediment. Res. 70 283-295.

Roy, P.S., Cowell, P.J., Ferland, M.A., Thom, B.G., 1994. Wave-dominated coasts. In: Carter, R.W.G., Woodroffe, C.D. (Eds.), Coastal Evolution: Late Quaternary Shoreline Morphodynamics. Cambridge University Press, Cambridge, pp. 121-186.

Sabatier, F., Samat, O., Ullmann, A., Suanez, S., 2009. Connecting large-scale coasta behaviour with coastal management of the Rhône delta. Geomorphology 107 79-89.

Schultz, L.G., 1964. Quantitative Interpretation of Mineralogical Composition from X Ray and Chemical Data for the Pierre Shale. U. S. Geological Survey. Prof. Paper 391-C.

Seranne, M. Anka, Z., 2005. South Atlantic continental margins of Africa: a comparison of the tectonic vs climate interplay on the evolution of equatorial west Africa and SW Africa margins. J. Afr. Earth Sci. 43, 283-300.

Shannon, L.V., Nelson, G., 1996. The Benguela: large scale features and processes and system variability. In: Wefer, W.H.B.G., Siedler, G., Webb, D. (Eds.), The South Atlantic: Present and Past Circulation. Springer, Berlin, pp. 163-210.

Silva, A.F., 2005. A geologia da República de Angola desde o Paleoarcaico ao Paleozóico Inferior. INETI, Alfragide.

Tamura, T., 2012. Beach ridges and prograded beach deposits as paleoenvironmental records. Earth Sci. Rev. 114, 279-297.

Van Maren, D.S., 2005. Barrier formation on an actively prograding delta system: the Red River Delta, Vietnam. Mar. Geol. 224, 123-143.

Velde, B., 1995. Origin and Mineralogy of Clays: Clays and the Environment Springer-Verlag, Berlin.

Wright, L.D., 1977. Sediment transport and deposition at river mouths: a synthesis. Geol. Soc. Am. Bull. 88.

Wright, L.D., 1985. Wave deltas. In: Davis, A.R. (Ed.), Coastal Sedimentary Environments. Springer-Verlag, New York, pp. 1-76. 